\title{
Influence of estuarine dynamics on macrobenthos spatial variability along the southeast continental shelf of Brazil
}

\author{
Ilana R. Zalmon ${ }^{1}$, Carlos Eduardo de Rezende ${ }^{1}$, Valeria G. Veloso ${ }^{2 \dagger}$, Ilana Sallorenzo ${ }^{3}$, \\ Rodolfo Paranhos ${ }^{4}$, Ana Paula Falcão ${ }^{5}$, Tito Cesar M. de Almeida ${ }^{1,6}$ \\ ${ }^{1}$ Universidade Estadual do Norte Fluminense. Av. Alberto Lamego 2000, Campos, 28013-602, RJ, Brazil. \\ E-mail: ilana@uenf.br \\ ${ }^{2}$ Universidade Federal do Estado do Rio de Janeiro. Av Pasteur 458, Rio de Janeiro, 22290-240, RJ. ${ }^{\dagger}$ in memoriam. \\ ${ }^{3}$ Universidade Federal Fluminense. Outeiro de São João Batista s/n, Niterói, 24020-140, RJ, Brazil. \\ ${ }^{4}$ Universidade Federal do Rio de Janeiro. Cidade Universitária. 21941-915, RJ, Brazil. \\ ${ }^{5}$ CENPES/PETROBRAS. Av Horácio Macedo, 950, Cidade Universitária, 21941-915, RJ, Brazil. \\ ${ }^{6}$ Universidade do Vale do Itajaí, Itajaí, 88302-130, SC, Brazil.
}

\begin{abstract}
Summary: Along the southeast continental shelf of Brazil, the Paraíba do Sul River (PSR) plays a fundamental role in sediment and nutrient transport. This study focuses on the contribution of the PSR and its effect on the benthic macrofauna. Physical and chemical analyses of the sediment were conducted, and the macrofauna were identified and counted. Multivariate analyses were used to compare the distribution patterns of the benthic assemblages related to the depth gradient over two sampling periods. The principal component analysis showed that shallow waters assemblages are mostly influenced by the environmental descriptors temperature, salinity and chlorophyll $a$, whereas pheophytin, degree of sediment sorting, total carbonate and organic carbon were correlated with benthic assemblages at greater depths. The high organic enrichment reflected an increase in surface and sub-surface deposit feeders such as the polychaetes Spiophanes sp. and Prionospio cristata and the crustacean Phtisica marina in the deeper stations, with a corresponding decrease in other trophic groups. This study provides evidence of differences in organic matter sources, from primary production in shallow waters to detritus in deep waters. These sources provide different niches for the corresponding macrofaunal assemblages along the continental shelf adjacent to the PSR, with species richness and abundance of benthic populations related to the river output.
\end{abstract}

Keywords: sediment; macrofauna; organic carbon; phytopigments; continental shelf; Paraíba do Sul River.

Influencia de la dinámica de estuarios sobre la variabilidad espacial de macrobentos a lo largo de la plataforma continental del sudeste de Brasil

Resumen: A lo largo de la plataforma continental del sudeste de Brasil, el río Paraíba do Sul (RPS) juega un papel fundamental en el transporte de sedimento y nutrientes. Este estudio se enfoca en la contribución del RPS y sus efectos sobre la macrofauna bentónica. Se condujeron análisis físicos y químicos del sedimento, y la macrofauna fue identificada y contada. Se realizaron análisis multivariados para comparar los patrones de distribución de los ensamblajes bentónicos relacionados al gradiente de profundidad en dos periodos de muestreo. El análisis de componentes principales (ACP) mostró que los ensamblajes de aguas poco profundas son influenciados principalmente por los descriptores ambientales de temperatura, salinidad, y clorofila $a$, mientras que la feofitina, grado de clasificación de sedimentos, carbonato total y el carbón orgánico estaban correlacionados a los ensamblajes bentónicos a mayores profundidades. El alto enriquecimiento orgánico se refleja en un incremento de detritívoros superficiales y sub-superficiales como los poliquetos Spiophanes sp. y Prionospio cristata y el crustáceo Phtisica marina en las estaciones más profundas, con el decrecimiento correspondiente en otros grupos tróficos. Este estudio provee evidencia de diferencias entre fuentes de materia orgánica, desde la producción primaria en aguas poco profundas hasta detrito en aguas profundas, que proveen distintos nichos a los ensamblajes macrofaunales correspondientes a lo largo de la plataforma continental adyacente al RPS, con la riqueza de especies y abundancia de las poblaciones bentónicas relativas al flujo del rio.

Palabras clave: sedimento; macrofauna; carbón orgánico; fitopigmentos; plataforma continental; río Paraíba do Sul.

Citation/Como citar este artículo: Zalmon I.R., de Rezende C.E., Veloso V.G., Sallorenzo I., Paranhos R., Falcão A.P., de Almeida T.C.M. 2015. Influence of estuarine dynamics on macrobenthos spatial variability along the southeast continental shelf of Brazil. Sci. Mar. 79(3): 379-391. doi: http://dx.doi.org/10.3989/scimar.04196.18A

Editor: X. Turon.

Received: December 11, 2014. Accepted: May 27, 2015. Published: June 23, 2015.

Copyright: (0) 2015 CSIC. This is an open-access article distributed under the Creative Commons Attribution-Non Commercial Lisence (by-nc) Spain 3.0. 


\section{INTRODUCTION}

Depositional organic matter $(\mathrm{OM})$ is a significant source of energy and elemental raw materials for most benthic communities, so sedimentary OM dynamics exert strong control over marine benthic biodiversity. Organic enrichment influences community composition by reducing diversity through the exclusion of low-tolerance species and increasing the biomass associated with the dominance of several opportunistic species (Pearson and Rosenberg 1978, Lardicci et al. 1993, Diaz-Castaneda and Harris 2004). An increase in the amount and quality of OM can lead to an increase in the biomass and density of the benthic organisms and also to dystrophic events, such as episodes of hypoxia or anoxia, which can cause massive reductions or elimination of the benthic fauna. Such phenomena are frequent and well documented in the northern Adriatic Sea (e.g., Ambrogi et al. 1990, Crema et al. 1991, Moodley et al. 1998).

Hydrodynamics and depositional environments, with their physical and chemical proprieties, have repeatedly been referred to as the main contributors to the variability of soft-bottom communities (Snelgrove and Butman 1994), which are influenced by characteristics of the bottom currents that favour sedimentation and/or resuspension and sediment transport, particularly in shallow waters (Sternberg 1984 in Leninhan and Micheli 2001, Akoumianaki et al. 2013). Sedimentation rates and the quality and quantity of $\mathrm{OM}$ in the sediment can determine the trophic structure, abundance, biomass and colonization pattern in the sediment (Marsh and Tenore 1990, Weston 1990, Dauer and Alden 1995). There is significant evidence that increased terrestrial sediment deposition in coastal zones is detrimental to the biodiversity and ecological value of estuarine and coastal habitats (Thrush et al. 2004). Field studies (Wijsman et al. 1999, Akoumianaki et al. 2013) have provided supporting evidence that sedimentary processes in coastal areas that are influenced by smaller rivers are related to the distance from riverine sources.

Ocean dynamics control the dispersion of particles by riverine plumes and their subsequent mixing and dilution within coastal and oceanic boundary currents, followed by their gradual sedimentation within the shelf area (Albuquerque et al. 2014). All of these sources and processes operate according to their own temporal and spatial constraints, creating a complex scenario for understanding the origins and fates of suspended particles at the ocean margin and their fluxes to the ocean floor (Liu et al. 2010, Schmidt et al. 2010)

The Paraíba do Sul River (PSR) plays an important role in the ecosystem of the southeast continental shelf of Brazil. A recent study showed that the water mixture ratio in the dry season ranges from 23 to $38 \mathrm{~km}^{2} \mathrm{~d}^{-1}$, whereas in the rainy period (summer months), it ranges from 65 to $68 \mathrm{~km}^{2} \mathrm{~d}^{-1}$ (Souza et al. 2010). According to Carvalho et al. (2002), the PSR shows a large interannual variation of suspended particulate matter discharge ( 0.8 to $2.0 \times 10^{6}$ t/year), whereas other results indicate a discharge of $0.3 \times 10^{6} \mathrm{t} / \mathrm{year}$ of dissolved organic carbon (Figueiredo et al. 2011, Ovalle et al. 2013). The water chemistry information associated with spectral mapping of the PSR plume suggest that the continental input provides an important contribution towards the macrobenthic distribution, abundance and diversity in open estuarine areas and continental shelves (Rudorff et al. 2011).

This study examines the species composition and distribution of the macrozoobenthic community according to distances from the PSR outfall and environmental variables in the water column and sediment in a coastal area of Campos Basin, along the southeast continental shelf of Brazil. We tested the hypothesis that, in the shallower coastal area under higher PSR influence, an increase in the abundance of benthic populations is expected because these species take advantage of the high organic nutrient inputs. In the outer shelf region, which is characterized by reduced sedimentation and resuspension levels, the low food inputs should result in lower species abundance.

\section{MATERIALS AND METHODS}

\section{Study site}

The Campos Basin is located in southeastern Brazil and includes a large portion of the coast of Rio de Janeiro and Espírito Santo States. The study area is located on the continental shelf north of Rio de Janeiro State (southern boundary $22^{\circ} 59^{\prime} \mathrm{S}, 39^{\circ} 93^{\prime} \mathrm{W}$; northern boundary $21^{\circ} 11^{\prime} \mathrm{S}, 40^{\circ} 78^{\prime} \mathrm{W}$ ), and it is adjacent to the mouth of the Paraíba do Sul River (Fig. 1A). The Tropical Water, Coastal Water and South Atlantic Central Water masses influence the study area. The latter penetrates the continental shelf during spring and summer and brings nutrient-rich waters (Silveira et al. 2000). The climate is characterized as warm subtropi$\mathrm{cal}$, and the annual average temperatures range from $18^{\circ} \mathrm{C}$ to $24^{\circ} \mathrm{C}$ (Marengo and Alves 2005). The seafloor includes areas with sand of different granulometric fractions and areas with elevated percentages of mud and/or gravel (Lana et al. 1996, Saavedra et al. 1999).

\section{Field sampling}

Two oceanographic sampling campaigns were completed: March 2009 (rainy season) and July 2009 (dry season). A valid temporal comparison was not possible because of a lack of replicated wet/dry season sampling, and then both surveys were considered as spatial replicates to reinforce the riverine influence, which must be discerned using spatial differences alone. Therefore, we used two temporal campaigns to define the similarities/differences among the sampling depths. The temporal descriptor was considered as a hierarchical factor in the spatial factor (latitudinal and longitudinal), representing the bathymetry and coastal distance.

The samples were collected in triplicate with a Van Veen grab at 53 stations from 12 to $100 \mathrm{~m}$ depth, covering a potential region that is reached by the sediment plume along the continental shelf (Fig. 1B), and then 

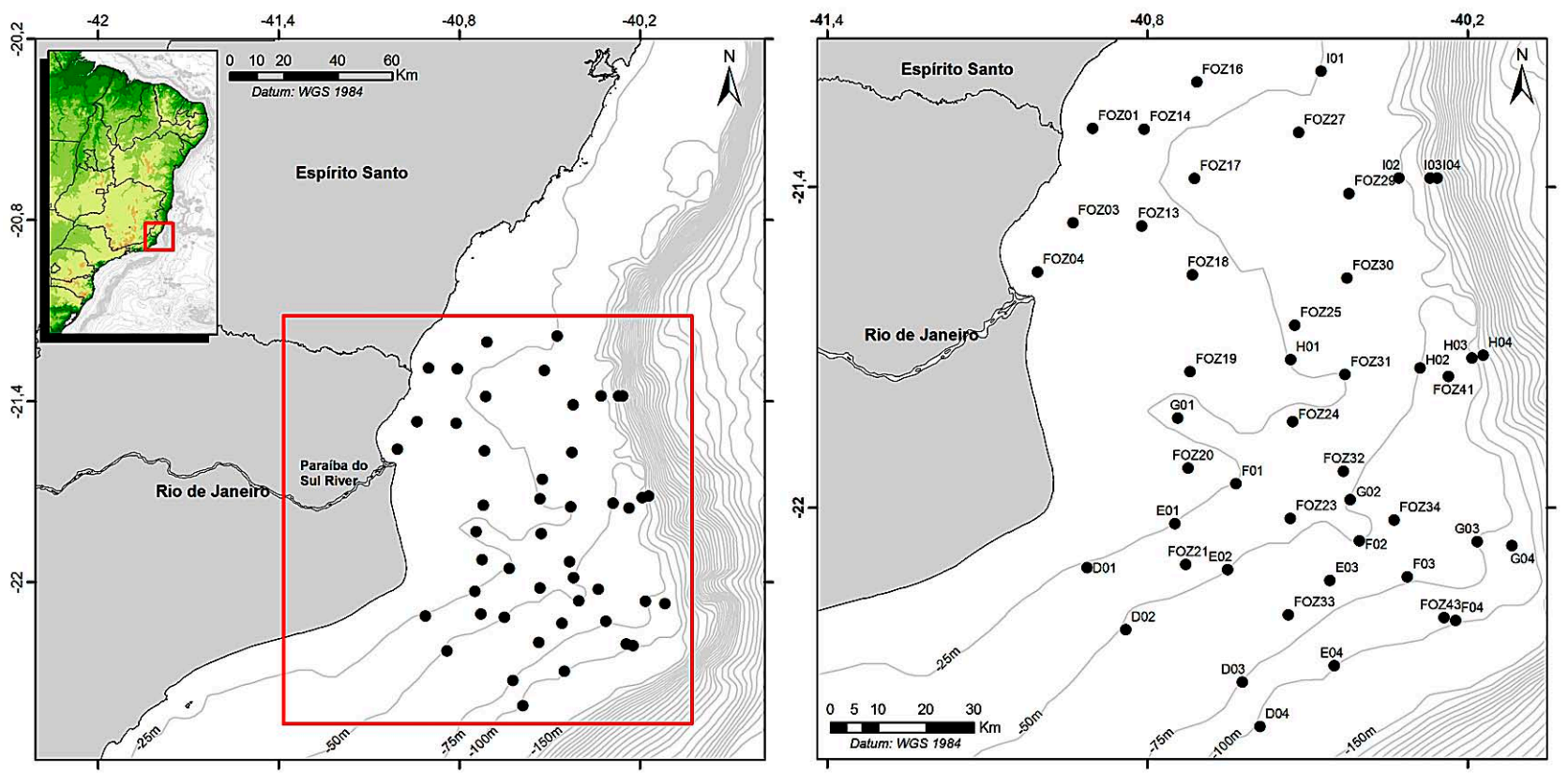

Fig. 1. - A, the study area on the northern coast of the Rio de Janeiro State and southern coast of Espírito Santo State. B, a map showing the locations and depths of the sampling sites.

grouped into four depth strata $(<30 \mathrm{~m}, 30-50 \mathrm{~m}, 50-$ $75 \mathrm{~m}$ and $75-100 \mathrm{~m}$ ). These stations were configured through a hypsometric curve considering depth versus isobaths $(<30 \mathrm{~m}$, internal shelf; $30-50 \mathrm{~m}$, medium shelf; $50-75 \mathrm{~m}$ and 75-100 m, external shelf). Four subsamples $\left(10 \times 10 \times 10 \mathrm{~cm}\right.$ and $\left.0.004 \mathrm{~m}^{3}\right)$ were collected from the superficial sediment of each sample. The macrofauna subsamples were fixed in buffered $10 \%$ formaldehyde. The sediment parameters (grain size distribution, sorting, total carbonate and organic carbon) were sampled independently using $10 \times 10 \times 2$ $\mathrm{cm}$ corers, and then frozen. The depth, temperature and salinity were measured in situ using a CTD profiler. For the analysis of bacterial abundance and phytopigments, aliquots of the upper layer of the sediment (0-2 $\mathrm{cm}$ ) were transferred into $2 \mathrm{ml}$ cryogenic tubes with the aid of sterile wooden spatulas (previously autoclaved) and strictly sterile conditions. Immediately after collection, the samples were preserved in liquid nitrogen where they remained until they were analysed in the sample-processing laboratory.

\section{Laboratory analysis}

The macrofauna subsamples were sieved through a 500- $\mu \mathrm{m}$ mesh, sorted, identified to the lowest possible taxonomic level and counted. On the sediment subsamples, the grain size distribution was determined by a particle analyser using laser diffraction (Shimadzu Model SALD-3101) in several fractions of the Wentworth scale (Suguio 1973), and classified using the degree of sorting. The total carbonate was determined by acid treatment using $1 \mathrm{~g}$ of dry sediment with 20 $\mathrm{ml}$ of $\mathrm{HCl} 1.0 \mathrm{M}$ overnight. The organic carbon (OC) was determined by a $\mathrm{CHN}$ analyser after removing the carbonate with $\mathrm{HCl} 1.0 \mathrm{M}$ added directly into the silver vials (Hedges and Stern 1984).
For the determination of pigments (chlorophyll and pheophytin), aliquots of approximately $1.0 \mathrm{~g}$ were weighed, and the pigments were extracted with $100 \%$ acetone for $24 \mathrm{~h}$ (in the dark at $4^{\circ} \mathrm{C}$ ) using a fluorimeter (Turner Designs TD-700). The calculations were based on procedures and equations described by Parsons et al. (1984), and the detection method was performed with a focus on metrology (Mattos 2001). The devices were calibrated with pure chlorophyll $a$ (Sigma C-6144), and the detection limit for this assay was $0.02 \mu \mathrm{g} \mathrm{g}^{-1}$.

\section{Data analysis}

Differences in water temperature and salinity were compared using two-sample t-tests of survey-specific estimates ( $\mathrm{n}=159$ for March 2009 and $\mathrm{n}=159$ for July 2009). A principal component analysis (PCA) was applied to both campaigns to define the similarities between the 53 sampling sites according to the environmental descriptors (continuous variables), and also to define which descriptors are most influencing the observed pattern.

The pattern of macrofauna distribution was compared among the four depth strata $(<30 \mathrm{~m}, 30-50 \mathrm{~m}$, $50-75 \mathrm{~m}$ and $75-100 \mathrm{~m}$ ) in both periods through a matrix of the transformed abundance data of the representative species (species with a relative abundance $>0.5 \%$ ) and ordinated (non-metric multidimensional scaling [nMDS]) using the Bray-Curtis similarity index (Clarke and Warwick 2001).

A permutational multivariate analysis of variance (Anderson 2001, 2005) was performed for a multivariate comparison of the macrofauna composition among the depth strata on both periods. The Bray-Curtis similarity distance was selected as a base for the PERMANOVA analyses. The species density log-transformed data were permuted 9999 times per analysis at 

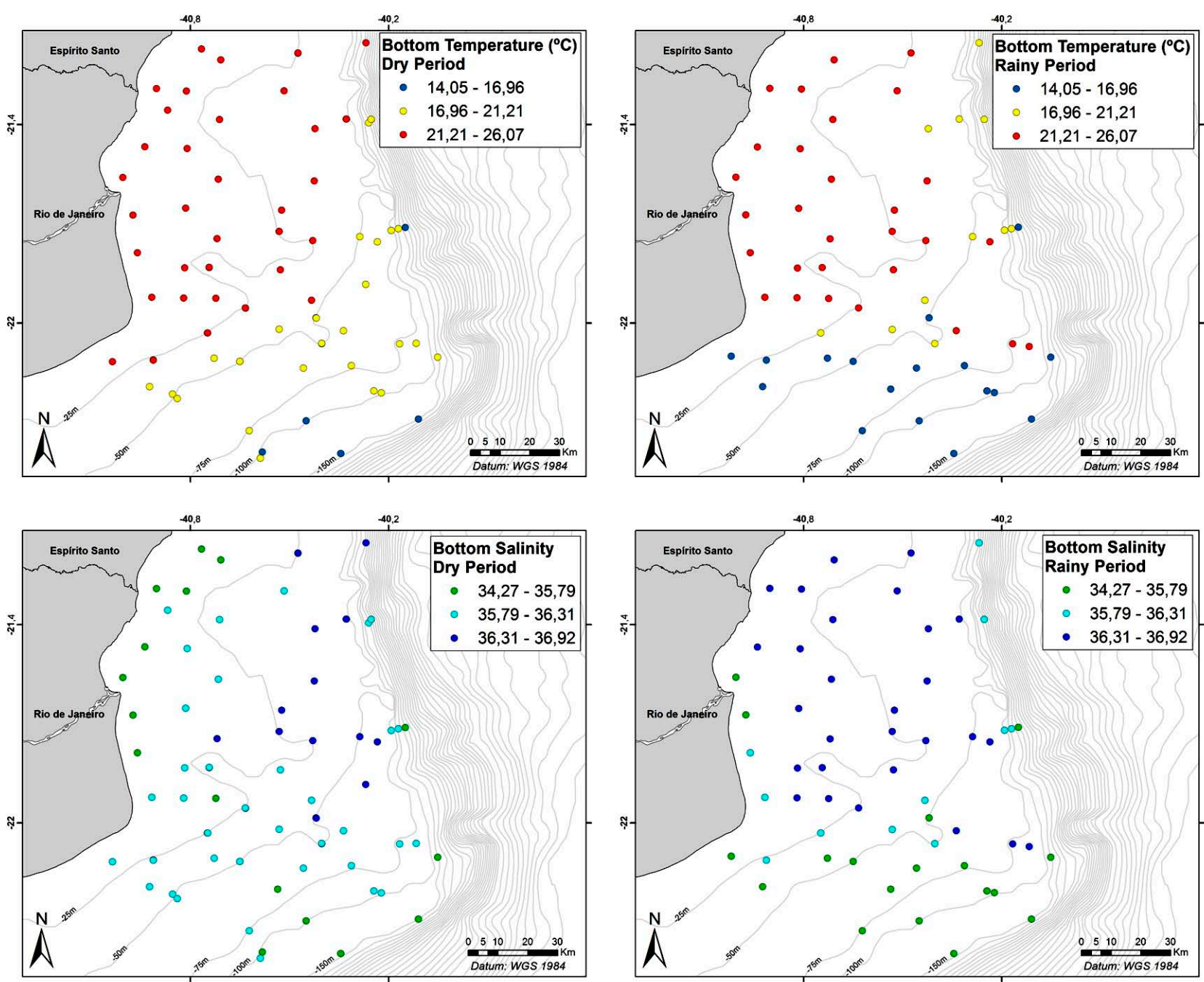

Fig. 2. - The mean temperature and salinity values at the 53 stations located along the southeast continental shelf of Brazil (A, temperature, dry period; B, temperature, rainy period; C, salinity, dry period; D, salinity, rainy period).

a significance level of 0.05 . The species' contributions to the similarity were calculated using the identification of the faunal associations (SIMPER). The multivariate analyses were performed using the PRIMER v. 6 statistical software (Clarke and Warwick 2001).

A canonical correspondence analysis (CCA) was used to correlate the macrofauna organisms (species with a relative abundance $>0.5 \%$ ) with the environmental variables temperature, salinity, pheophytin, chlorophyll $a$ and the sediment parameters sorting, total carbonate and total $\mathrm{OC}$, which were the only significant variables in the prior permutational test. The significance of the canonical axes and variables was determined using Monte Carlo tests and permutations (Ter Braak 1986) using the software programs CANOCO and MVSP 3.13, respectively.

\section{RESULTS}

\section{Abiotic data}

During the dry and rainy seasons, the salinity of the bottom water ranged between 34.3 and 36.9 and 35.4 and 36.5 , respectively $\left(t_{\text {est }}=5.33\right.$, D.F. $=160.3$ and $\mathrm{p}<0.0001)$ and the temperature ranged from $14.4^{\circ} \mathrm{C}$ to $26.1^{\circ} \mathrm{C}$ and $14.0^{\circ} \mathrm{C}$ to $23.1^{\circ} \mathrm{C}$, respectively. Therefore, shallow water samples from rainy periods have significantly lower temperature and higher salinity $\left(\mathrm{t}_{\text {est }}=2.03\right.$, D.F. $=133.5$ and $\mathrm{p}=0.04$ ) (Fig. 2).

The sediment was predominantly sand (93\%), except at stations E1 and 4 during the rainy period, and I4, 7 and 8 during the dry period, which exhibited a predominance of silt; stations $\mathrm{H} 4$ and $\mathrm{I} 2$ exhibited a predominance of gravel (Fig. 3, Appendix 1). The degree of sediment sorting varied from very poorly or poorly $(50 \%)$ to moderately selected (50\%) (Appendix 1).

The grain size distribution ranged from very coarse sand to medium silt $(-0.31$ to $6.96 \theta)$ in the rainy period and from very fine gravel to fine silt $(-1.43$ to $5.25 \theta)$ in the dry period (Figs 3A, B). The total carbonate and $\mathrm{OC}$ ranged from $<0.01$ to $11.6 \%$ and 0.08 to $1.53 \%$, respectively, in the dry season and from $<0.01 \%$ to $11.5 \%$ and $0.05 \%$ to $0.92 \%$, respectively, in the rainy season. Chlorophyll $a$ ranged from 0.02 to $7.36 \mu \mathrm{g} \mathrm{g}^{-1}$ in the dry season and from 0.26 to $7.23 \mu \mathrm{g} \mathrm{g}^{-1}$ in the rainy season. Pheopigments were also low, ranging from 0.02 to $12.90 \mu \mathrm{g} \mathrm{g}^{-1}$ in the dry season and 0.30 to $7.29 \mu \mathrm{g} \mathrm{g}^{-1}$ in the rainy season. Although OC was 
lower closer to the outfall PSR stations, the chlorophyll/pheophytin ratio was higher (Figs 3C, D, E, F).

The two principal axes indicated by the PCA explained $\sim 52 \%$ of the total variance in both campaigns. Axis $1(34.5 \%)$ revealed that the shallower stations $(<50 \mathrm{~m})$, mainly on the left side, were most strongly influenced by temperature, salinity and chlorophyll $a$ (Fig. 4) in both the rainy and dry periods. The diagram reveals a direct relationship between pheophytin and the sediment parameters sorting, total carbonate and $\mathrm{OM}$ in the deeper ranges (Fig. 4).

\section{Taxonomic composition}

The benthic macrofauna included annelids, crustaceans, molluscs, echinoderms, nemerteans and sipunculids. A total of 71415 individuals were collected during the two sampling campaigns, of which 44574 individuals and 1413 species were sampled during the rainy period and 26841 individuals and 1091 species were sampled during the dry period. Considering a relative abundance of over $0.5 \%$, a total of 32 species were recorded in the rainy period, whereas 42 species were obtained during the dry season (Table 1). Among the observed taxonomic groups, Polychaeta and Crus- tacea showed the highest abundance values, followed by Mollusca, Echinodermata, Nemertea and Sipuncula (Table 1). The most representative taxa differed between periods, with a predominance of the polychaetes Chone americana and Spiophanes sp. 1 and the crustacean Phtisica marina in the rainy season and the polychaete Goniadides carolinae and crustaceans Chevalia anomala and Chevalia sp. 2 in the dry season.

\section{Macrofauna assemblages and spatial comparisons}

The pattern of species associations differed significantly between depths considering both sampling periods ( $p$ seudo- $\mathrm{F}=5.623$; $\mathrm{p}=0.001$ ). MDS ordination shows at the bottom of the diagram a close association of macrofauna mainly in the deepest stations (75-100 m) in both periods (Fig. 5), which was confirmed by PERMANOVA, and significant differences $(\mathrm{p}>0.05)$ between the other depth strata (Table 2). SIMPER analysis shows in both periods that Goniadides carolinae, Sphaerosyllis sp. 3 and Protodorvillea kefersteini contributed the most $(22 \%)$ to the shallow and intermediate stations $(<30 \mathrm{~m}$ and $30-50 \mathrm{~m})$, whereas the polychaetes Spiophanes sp. B (20\%) and Prionospio cristata $(12 \%)$ and the crustacean Phtisica marina (20\%),

Table 1. - Total mean number of individuals per station and relative abundance of the most representative taxa ( $>0.5 \%$ abundance) during the rainy and dry periods of 2009 at 53 stations (P, Polychaeta; C, Crustacea; and M, Mollusca).

\begin{tabular}{|c|c|c|c|c|c|}
\hline Taxa - Rainy period & No inds & $\%$ & Taxa - Dry period & No inds & $\%$ \\
\hline Chone americana Day, 1973(P) & 1305 & 8.7 & Goniadides carolinae Day, 1973 (P) & 437 & 4.6 \\
\hline Phtisica marina Slabber, 1769(C) & 731 & 4.9 & Chevalia anomala Souza-Filho, 2010 (C) & 305 & 3.2 \\
\hline Spiophanes sp. B(P) & 500 & 3.3 & Chevalia sp. 2 (C) & 274 & 2.9 \\
\hline Goniadides carolinae Day, 1973(P) & 440 & 2.9 & Exogone (Exogone) sp. $2(\mathrm{P})$ & 213 & 2.2 \\
\hline Chevalia sp. $2(\mathrm{C})$ & 421 & 2.8 & Prionospio cristata Foster, 1971 (P) & 200 & 2.1 \\
\hline Sphaerosyllis sp. 3(P) & 333 & 2.2 & Sphaerosyllis sp. $3(\mathrm{P})$ & 160 & 1.7 \\
\hline Aricidea (Acmira) cf. taylori $(\mathrm{P})$ & 297 & 2.0 & Aphelochaeta spp. (P) & 144 & 1.5 \\
\hline Exogone (Exogone) sp. 2(P) & 295 & 1.9 & Protodorvillea kefersteini (McIntosh, 1869) (P) & 141 & 1.5 \\
\hline Parapseudini sp. (P) & 258 & 1.7 & Nemertea & 135 & 1.4 \\
\hline Protodorvillea kefersteini (McIntosh, 1869) (P) & 246 & 1.6 & Spiophanes sp. A (P) & 133 & 1.4 \\
\hline Chevalia setosa Souza-Filho, Souza \& Valério-Berardo, 2010 (C) & 236 & 1.5 & Sipuncula & 128 & 1.3 \\
\hline Echinodermata & 216 & 1.4 & Hesionura sp. (P) & 111 & 1.1 \\
\hline Paraleiopus macrochelis Brum, 1978 (P) & 189 & 1.2 & Paraprionospio tamaii Delgado-Blas, 2004 (P) & 105 & 1.1 \\
\hline Nemertea & 187 & 1.2 & Mediomastus californiensis Hartman, 1944 (P) & 103 & 1.0 \\
\hline Hesionura laubieri (Hartmann-Schröeder, 1963)(P) & 150 & 1.0 & Heteropodarke spp. (P) & 98 & 1.0 \\
\hline Perkinsyllis sp. $1(\mathrm{P})$ & 134 & 0.9 & Laonice weddellia Hartman, 1978 (P) & 98 & 1.0 \\
\hline Ampelisca brevisimulata Barnard, 1954(C) & 122 & 0.8 & Dorvilleidae sp. $6(\mathrm{P})$ & 96 & 1.0 \\
\hline Aricidea (Aricidea) albatrossaePettibone, $1957(\mathrm{P})$ & 121 & 0.8 & Apoprionospio dayi Foster, 1969 (P) & 95 & 1.0 \\
\hline Prionospio cristata Foster, 1971 (P) & 119 & 0.8 & Aricidea (Acmira) cf. taylori $(\mathrm{P})$ & 95 & 1.0 \\
\hline Mediomastus californiensis Hartman, 1944 (P) & 110 & 0.7 & Echinodermata & 92 & 0.9 \\
\hline Cirrophorus sp. 3 (P) & 109 & 0.7 & Cirrophorus sp. $3(\mathrm{P})$ & 88 & 0.9 \\
\hline Chevalia anomala $(\mathrm{C})$ & 101 & 0.6 & Chone americana Day, $1973(\mathrm{P})$ & 84 & 0.9 \\
\hline Heteropodarke sp.1 (P) & 101 & 0.6 & Perkinsyllis sp. 1 (P) & 79 & 0.8 \\
\hline Kamakidae sp. 2 (C) & 98 & 0.6 & Chevalia caetes Souza-Filho, 2010 (C) & 76 & 0.8 \\
\hline Laonice weddellia Hartman, 1978 (P) & 91 & 0.6 & Chaetozone sp. $(\mathrm{P})$ & 69 & 0.7 \\
\hline Prosphaerosyllis sp.(P) & 91 & 0.6 & Parapseudini sp. (C) & 68 & 0.7 \\
\hline Aphelochaeta sp.(P) & 91 & 0.6 & Ampelisca youngi Valério-Berardo, 2010 (C) & 67 & 0.7 \\
\hline Sipuncula & 89 & 0.6 & Praxillella praetermissa (Malmgren, 1865) (P) & 67 & 0.7 \\
\hline Puelche sp. 1 (C) & 88 & 0.5 & Sphaerosyllis sp. $7(\mathrm{P})$ & 65 & 0.6 \\
\hline Parexogone sp. 4(P) & 85 & 0.5 & Parexogone sp. $6(\mathrm{P})$ & 65 & 0.6 \\
\hline Mooreonuphis intermedia (Kingberg, 1865) (P) & 85 & 0.5 & Pteria colymbus (Röding, 1798) (M) & 63 & 0.6 \\
\hline \multirow[t]{11}{*}{ Heteropodarke sp. $2(\mathrm{P})$} & 75 & 0.5 & Paraehlersia sp. $1(\mathrm{P})$ & 62 & 0.6 \\
\hline & & & Exogone (Exogone) sp. $3(\mathrm{P})$ & 62 & 0.6 \\
\hline & & & Prosphaerosyllis isabellae $(\mathrm{P})$ & 60 & 0.6 \\
\hline & & & Parexogone sp. $3(\mathrm{P})$ & 60 & 0.6 \\
\hline & & & Syllis guidae Nogueira, Yuda-Guarin, 2008 (P) & 57 & 0.6 \\
\hline & & & Levinsenia sp. 1 (P) & 56 & 0.6 \\
\hline & & & Aricidea (Acmira) cf. catharinae $(\mathrm{P})$ & 56 & 0.5 \\
\hline & & & Loandalia sp. (P) & 55 & 0.5 \\
\hline & & & Ericthonius sp. 2 (C) & 51 & 0.5 \\
\hline & & & Mooreonuphis intermedia (Kingberg, 1865) (P) & 50 & 0.5 \\
\hline & & & Cirratulidae sp. (P) & 47 & 0.5 \\
\hline
\end{tabular}



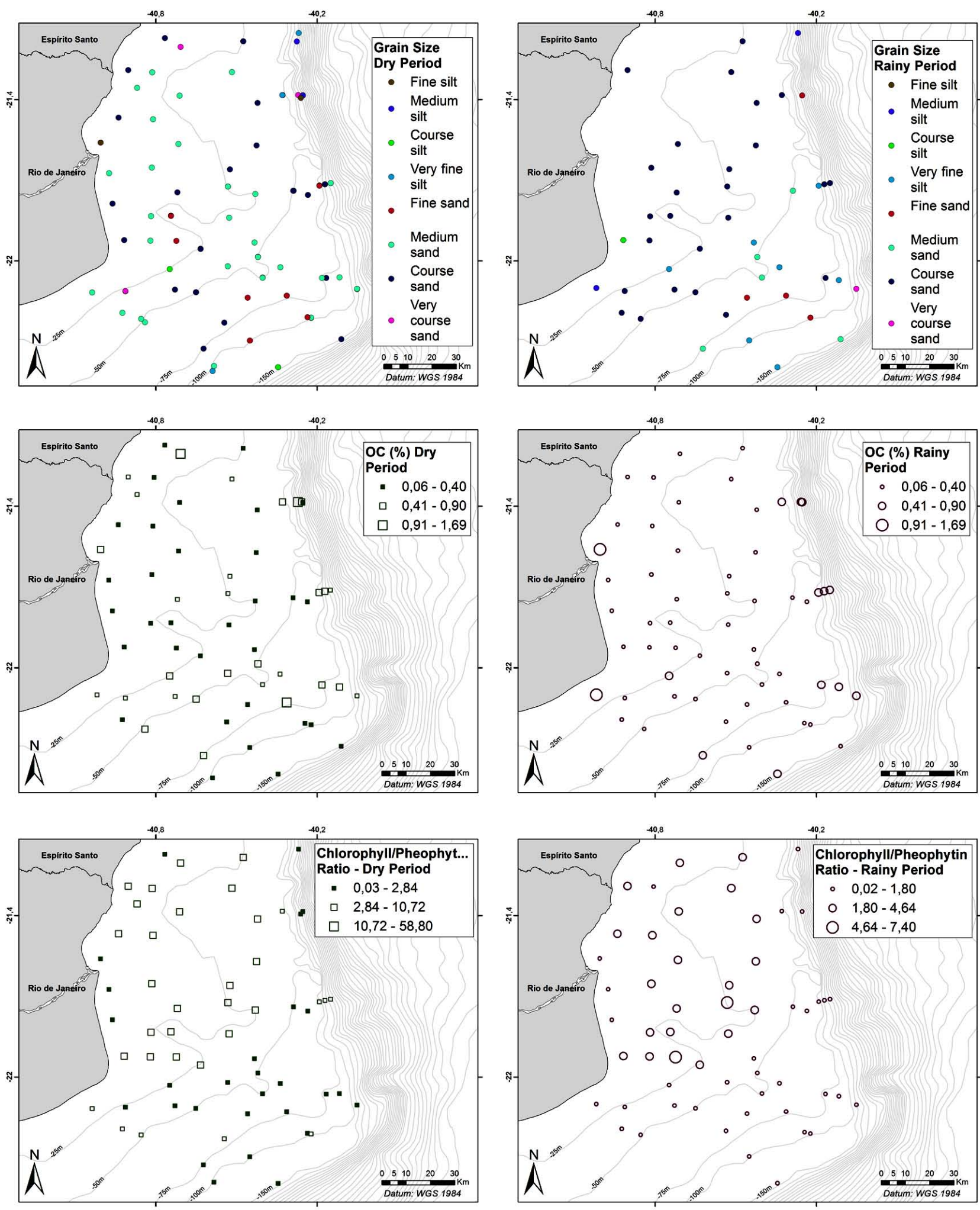

Fig. 3. - The mean grain size distribution, organic carbon (OC) values and chlorophyll/pheophytin ratio at the 53 stations located on the southeast continental shelf of Brazil (A, grain size, dry period; B, grain size, rainy period; C, OC, dry period; D, OC, rainy period; E, chlorophyll/ pheophytin ratio, dry period; F, chlorophyli/pheophytin ratio, rainy period).

which are mainly deposit feeders, predominated at the deeper stations (50-75 $\mathrm{m}$ and 76-100 $\mathrm{m})$.

The CCA extracted two significant axes that explained $14 \%$ of the variation in the abundances of the most representative taxa (see Table 1), of which $60 \%$ were attributed to the considered environmental variables (Table 3). Axis 1 was responsible for $11.5 \%$ of the variation, with pheophytin, sorting, temperature 


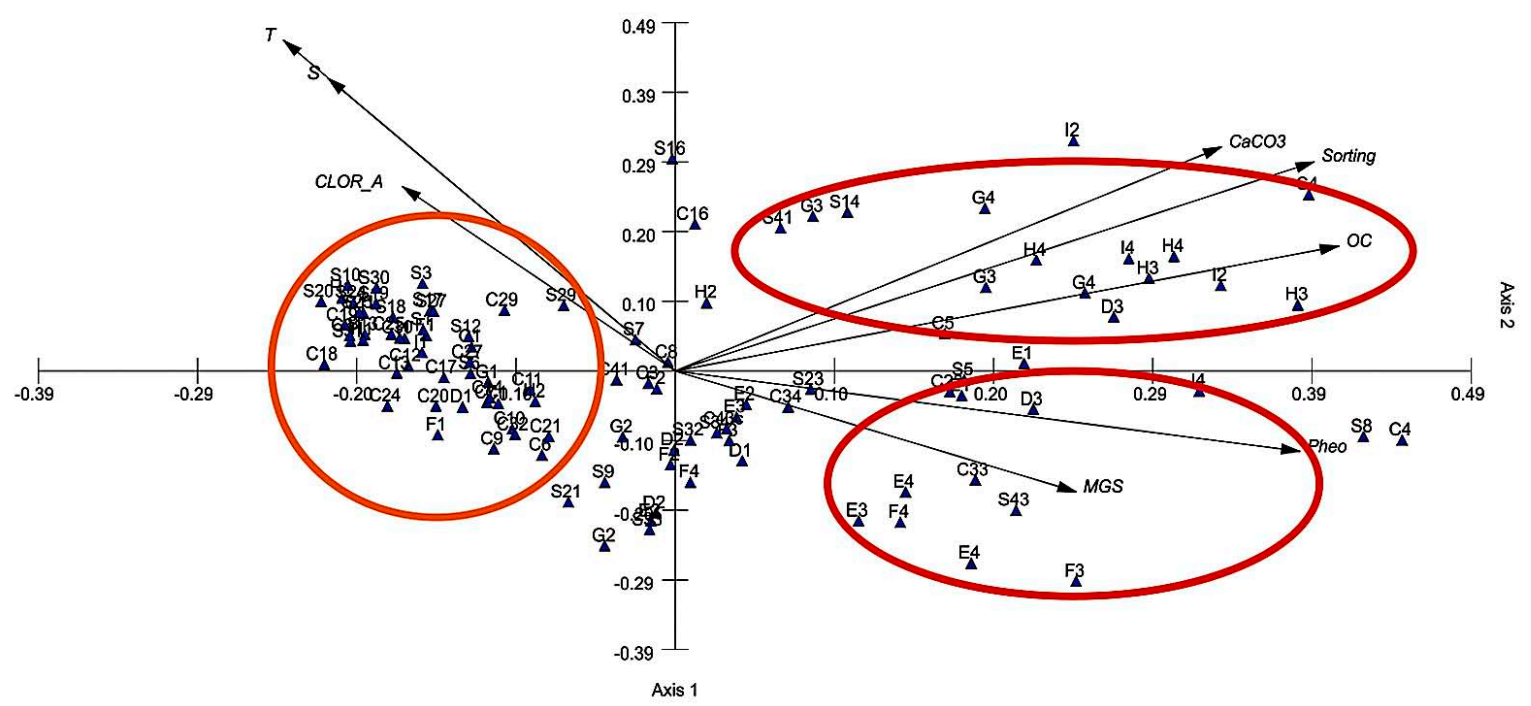

Fig. 4. - The principal component analysis (PCA) for the environmental variables water temperature and salinity, and sediment parameters that included pheophytin (Pheo), chlorophyll $a(\mathrm{Chl} a)$, organic carbon $(\mathrm{OC})$, total carbonate $\left(\mathrm{CaCO}_{3}\right)$ and sorting. Orange circle, shallower stations; red circles, deeper stations. Data from the 53 stations sampled during the rainy and dry periods of 2009 are shown on Appendix 1.

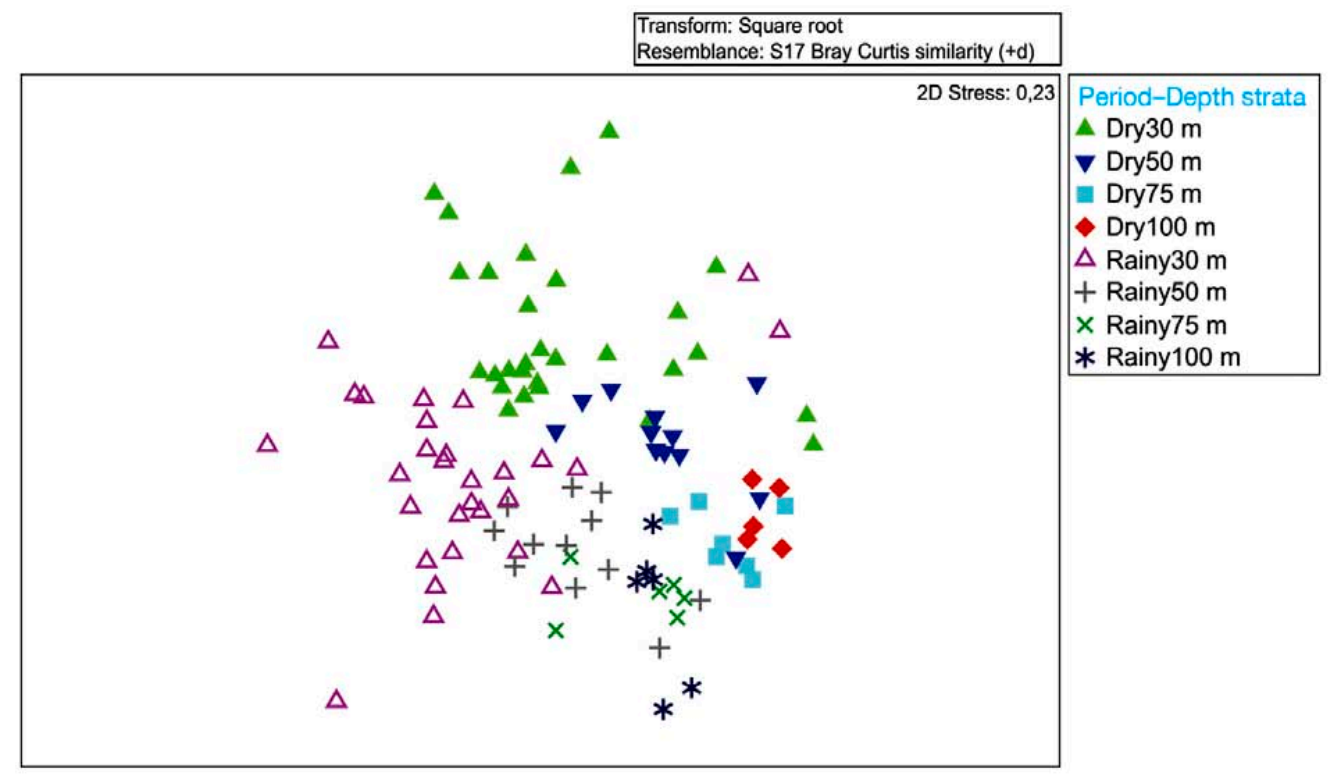

Fig. 5. - MDS relative to the dry and wet period collection and depths of 30, 50, 75 and $100 \mathrm{~m}$ in each period.

and OC showing the highest correlations and being responsible for the majority of the variation $(56 \%)$ (Table 4). This axis indicated an association of species related to shallower depths ( $<30 \mathrm{~m}$ and $31-50 \mathrm{~m})$, such as Parexogone sp. 3, Parexogone sp. 4, P. macrochelis and Sphaerosyllis sp. 3, which were positively correlated with temperature and chlorophyll and negatively correlated with sorting and pheophytin (Fig. 6A). The samples distribution along axis 1 indicated a gradient related to bathymetry, with the shallow stations on the positive side of the axis and the deeper stations on the negative side (Fig. 6B); this distribution also highlighted the relationships of OM with depth, which was represented by the highest degree of selection, and the highest concentrations of pheophytin and total carbonate.

\section{DISCUSSION}

This study examined the macrozoobenthic composition and distribution according to distances of the PSR outfall in a coastal area of Campos Basin, and provided evidence of differences in OM sources, from primary production in shallow waters to detritus in deep waters. These sources provided different niches for the corresponding macrofaunal assemblages, and higher species richness and abundance of benthic populations on the continental shelf adjacent to the PSR.

A former study at the PSR estuarine system showed the river influence on the structural pattern and composition of the benthic macrofauna exclusively on the inner shelf $(<50 \mathrm{~m})$ of the northern coast of Rio de Janeiro (Zalmon et al. 2013). The authors related 
Table 2. - Pair-wise tests results from PERMANOVA of the macrofaunal assemblages between the depth strata $(30,50,75$ and $100 \mathrm{~m})$ and periods (dry and rainy). NS: $\mathrm{p}>0.05$

\begin{tabular}{|c|c|c|c|c|}
\hline Groups & $\mathrm{t}$ & $\mathrm{P}($ perm $)$ & Unique perms & $\mathrm{P}(\mathrm{MC})$ \\
\hline Dry 30 m, Dry 50 m & 2.3098 & 0.001 & 999 & 0.001 \\
\hline Dry 30 m, Dry 75 m & 2.9970 & 0.001 & 998 & 0.001 \\
\hline Dry 30 m, Dry 100 m & 2.5328 & 0.001 & 997 & 0.001 \\
\hline Dry $30 \mathrm{~m}$, Rainy $30 \mathrm{~m}$ & 2.9238 & 0.001 & 998 & 0.001 \\
\hline Dry $30 \mathrm{~m}$, Rainy $50 \mathrm{~m}$ & 2.9822 & 0.001 & 997 & 0.001 \\
\hline Dry 30 m, Rainy 75 m & 2.8387 & 0.001 & 997 & 0.001 \\
\hline Dry $30 \mathrm{~m}$, Rainy $100 \mathrm{~m}$ & 2.7242 & 0.001 & 996 & 0.001 \\
\hline Dry $50 \mathrm{~m}$, Dry $75 \mathrm{~m}$ & 1.8861 & 0.001 & 990 & 0.011 \\
\hline Dry $50 \mathrm{~m}$, Dry $100 \mathrm{~m}$ & 1.9680 & 0.002 & 920 & 0.006 \\
\hline Dry 50 m, Rainy 30 m & 2.9714 & 0.001 & 998 & 0.001 \\
\hline Dry $50 \mathrm{~m}$, Rainy $50 \mathrm{~m}$ & 2.3537 & 0.001 & 997 & 0.001 \\
\hline Dry 50 m, Rainy 75 m & 2.5633 & 0.001 & 965 & 0.001 \\
\hline Dry $50 \mathrm{~m}$, Rainy $100 \mathrm{~m}$ & 2.6949 & 0.001 & 978 & 0.001 \\
\hline Dry 75 m, Dry 100 m & 1.2318 & $0.137 \mathrm{NS}$ & 550 & 0.183 \\
\hline Dry 75 m, Rainy $30 \mathrm{~m}$ & 3.0514 & 0.001 & 997 & 0.001 \\
\hline Dry 75 m, Rainy $50 \mathrm{~m}$ & 2.5958 & 0.001 & 992 & 0.001 \\
\hline Dry 75 m, Rainy 75 m & 2.1601 & 0.002 & 760 & 0.005 \\
\hline Dry 75 m, Rainy $100 \mathrm{~m}$ & 2.4070 & 0.001 & 743 & 0.003 \\
\hline Dry 100 m, Rainy 30 m & 2.7597 & 0.001 & 996 & 0.001 \\
\hline Dry 100 m, Rainy 50 m & 2.6855 & 0.001 & 909 & 0.001 \\
\hline Dry 100 m, Rainy 75 m & 2.4358 & 0.004 & 405 & 0.001 \\
\hline Dry 100 m, Rainy 100 m & 2.2502 & 0.005 & 402 & 0.005 \\
\hline Rainy 30 m, Rainy $50 \mathrm{~m}$ & 2.2184 & 0.001 & 998 & 0.001 \\
\hline Rainy 30 m, Rainy 75 m & 2.5204 & 0.001 & 998 & 0.001 \\
\hline Rainy 30 m, Rainy 100 m & 2.5815 & 0.001 & 999 & 0.001 \\
\hline Rainy 50 m, Rainy 75 m & 1.5697 & 0.024 & 969 & 0.031 \\
\hline Rainy 50 m, Rainy 100 m & 2.0245 & 0.001 & 975 & 0.002 \\
\hline Rainy 75 m, Rainy 100 m & 1.3581 & $0.060 \mathrm{NS}$ & 410 & 0.118 \\
\hline
\end{tabular}

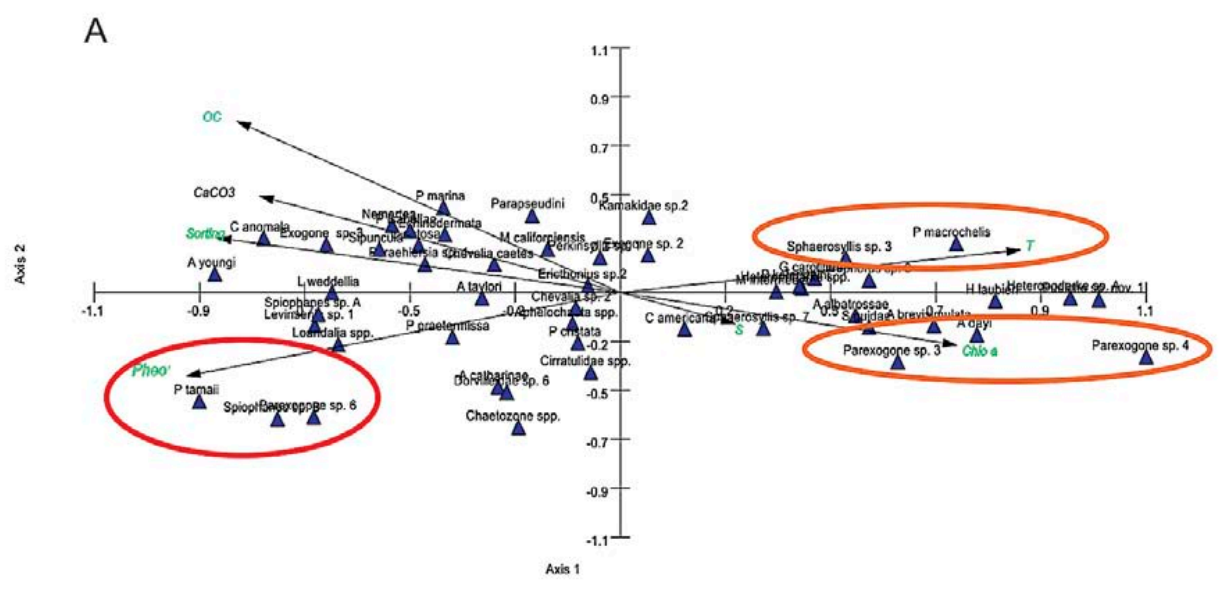

B

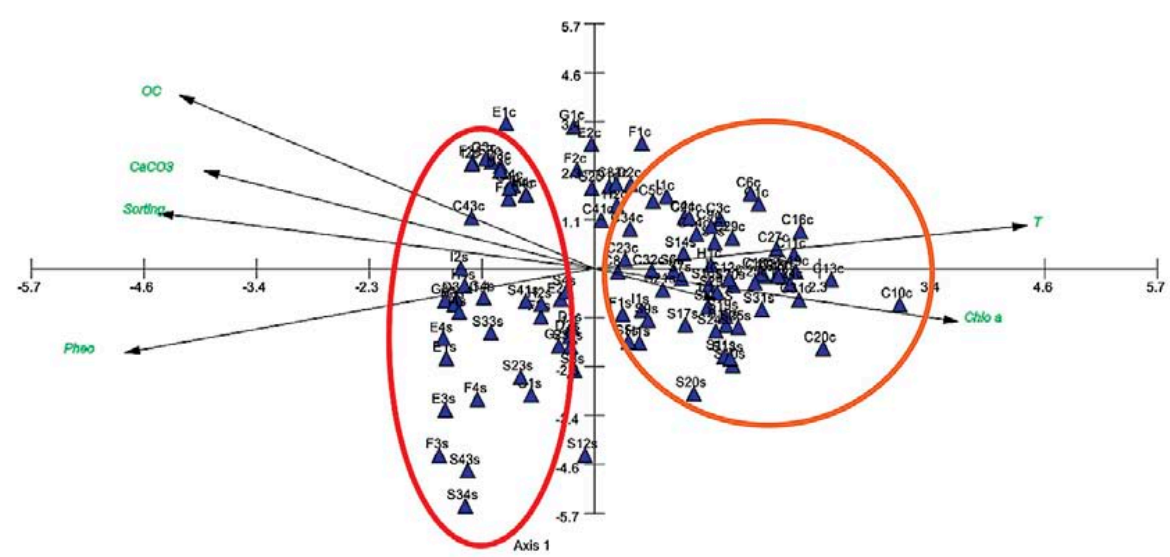

Fig. 6. - Canonical correspondence analysis of (A) the taxa with $>0.5 \%$ abundance (see Table 1) vs. environmental parameters (T, temperature; $\mathrm{S}$, salinity; $\mathrm{OC}$, organic carbon; $\mathrm{CaCO}_{3}$, total carbonate; $\mathrm{Chl} a$, chlorophyll $a$; Pheo, pheophytin; and sorting) and (B) the sampling stations (see Fig. 1) vs. the above environmental parameters. Orange and red circles: species/environmental parameters related to shallower stations and deeper stations, respectively. Data from the 53 stations sampled during the rainy and dry periods of 2009 are shown on Appendix 1. 
Table 3. - Results of the canonical correspondence analysis applied to the species and environmental variables. The Monte Carlo test was used for significance of the canonical axes.

\begin{tabular}{lcc}
\hline Axes & 1 & 2 \\
\hline Eigenvalues & 0.254 & 0.058 \\
Species-environment correlations & 0.873 & 0.572 \\
Cumulative \% variance of species data & 11.500 & 14.100 \\
Cumulative \% of species-environment relation & 56.300 & 60.000 \\
Summary of Monte Carlo test & & \\
Test of significance of first canonical axis: eigenvalue $=0.254$ \\
F-ratio $=12.761$ \\
P-value $=0.020$ \\
Test of significance of all canonical axes: Trace $=0.452$ \\
F-ratio $=3.606$ \\
P-value $=0.020$
\end{tabular}

Table 4. - CCA analysis: species-environmental variables correlations on axes 1 and 2, highlighting the significant correlations according to the Monte Carlo permutational test.

\begin{tabular}{lcc}
\hline & SPEC axis 1 & SPEC axis 2 \\
\hline $\mathrm{CaCO}_{3}$ & -0.593 & 0.340 \\
Sorting & $\mathbf{- 0 . 6 6 3}$ & 0.193 \\
$\mathrm{OC}$ & $\mathbf{- 0 . 6 3 1}$ & $\mathbf{0 . 6 0 4}$ \\
$\mathrm{Chl} a$ & 0.553 & -0.186 \\
Pheo & $\mathbf{- 0 . 7 1 4}$ & -0.295 \\
$\mathrm{~T}$ & $\mathbf{0 . 6 5 8}$ & 0.150 \\
$\mathrm{~S}$ & 0.189 & -0.110 \\
\hline
\end{tabular}

the community structure and environmental variations to the PSR discharge, while the present study of the benthic assemblages distinguished between the deepest $(75-100 \mathrm{~m})$ and shallowest $(<50 \mathrm{~m})$ stations in the rainy and dry periods.

The grain size distribution and moderately sorted sediments in the dry period reflected a lower hydrodynamic regime and more heterogeneous sedimentary environment. The macrobenthic community showed significant variation in composition and abundance influenced by the environmental parameters sorting, total organic carbon, temperature and pheophytin, and might suggest a strong link between OC, which is the chief characteristic of the PSR estuary, and the macrobenthic community. In parallel, the analysis showed that the abiotic variables were controlled by the riverine discharge of compounds such as chlorophyll and OC in the sediment, which had higher values in the rainy/summer season. Samples with higher OC and chlorophyll values were observed in areas under riverine influence, and this finding was interpreted as an indicator of this influence. Although autochthonous inputs could also be considered as sources for OC and chlorophyll, the spatial distribution supports the river as the important source. Oliveira et al (2013), using lipids as biomarkers to distinguish autochthonous from allochthonous sources, showed the predominance of primary (phytoplankton) and secondary (zooplankton) production over terrestrial derived material during winter and summer between 2008 and 2009. However, the nutrient supplies from continental outflow were evident during the summer period, and increased the marine production (primary and secondary) especially in shallow waters (total lipids in winter $<30 \mathrm{~m}, \sim 1.4$ to $3.2 \mathrm{mg} \mathrm{g}^{-1}$; TOC $30-50$ $\mathrm{m}, \sim 0.8$ to $1.2 \mathrm{mg} \mathrm{g}^{-1} ; 50-75 \mathrm{~m}, \sim 0.9$ to $2.4 \mathrm{mg} \mathrm{g}^{-1} ; 75-$ $100 \mathrm{~m}, \sim 1.0$ to $3.0 \mathrm{mg} \mathrm{g}^{-1}$; summer $<30 \mathrm{~m}, \sim 1.5$ to 6.4 $\mathrm{mg} \mathrm{g}^{-1} ; 30-50 \mathrm{~m}, \sim 1.6$ to $1.8 \mathrm{mg} \mathrm{g}^{-1} ; 50-75 \mathrm{~m}, \sim 1.1$ to $2.0 \mathrm{mg} \mathrm{g}^{-1} ; 75-100 \mathrm{~m}, \sim 0.8$ to $1.4 \mathrm{mg} \mathrm{g}^{-1}$ ).

Most differences between sampling stations emerged when comparing the assemblages at $<50$ $\mathrm{m}$ with those at $>75 \mathrm{~m}$. The deeper stations were less affected by the PSR outflows and the sediment mainly characterized by relict sands, with relatively low OC. Thus, they showed a different composition compared with the shallower stations, characterized by several carnivorous, omnivorous and burrowing polychaetes as Parexogone spp., P. macrochelis and Sphaerosyllis sp. The PSR plume only reaches the centre of the basin in summer, when the currents are stronger (>4-5 knots/s: Zalmon et al. 2002, Santos et al. 2010). These additional inorganic supplies fuel primary production in the area which, combined with the export dynamics of dissolved and particulate materials correlated to the rainfall and RPS flow rate (Souza and Knoppers 2003, Figueiredo et al. 2011), contribute to temporary summer deposit formation at the seabed. The high organic enrichment reflected an increase in surface and sub-surface deposit feeder species such as the polychaetes Spiophanes sp. and Prionospio cristata and the crustacean Phtisica marina at the deeper stations, with a corresponding decrease in the other trophic groups, particularly the suspension feeders.

Several models have been proposed to explain the relationship between OM content in the sediment and macrozoobenthic community structure (Pearson and Rosenberg 1978, Weston 1990, Dauwe et al. 1998). Species composition and distribution at the coastal stations considered in this study appeared to be consistent with the most widely accepted model proposed by Pearson and Rosenberg (1978), who suggested that, as the OM content increases, the community ultimately changes to primarily surface deposit feeders. The dominance of suspension feeders suggests less extreme conditions along the northern coast of Rio de Janeiro than in the coastal areas of other eutrophicated seas, such as the Baltic Sea, the Gulf of Mexico and the Black Sea, where predators are the main trophic group (Moodley et al. 1998, Rabalais et al. 2002).

River outflows and periodic dystrophic events are recognized driving forces that determine the structure and composition of the macrozoobenthic community in many estuarine and coastal ecosystems (Seliger et al. 1985, Rabalais et al. 2002). Along the north coast of Rio de Janeiro, the distribution of the macrozoobenthic community suggests an intermittent recovery from periodic and seasonal events that are maintained for long periods of time and also from indefinite, immature, transitory successional stages caused by the increasing frequency of $\mathrm{OM}$ in the summer months or rainy season. In addition to this natural process, bottom trawl fishery, which is a common source of income for the local population on the north coast of Rio de Janeiro (Costa and Di Beneditto 2009), could also disturb the sediment and associated communities. The intense fishing activity of the region is concentrated mainly in the isobaths below $30 \mathrm{~m}$ and certainly influences the dynamics of the benthic macrofauna. 
Despite its importance as a food source, highparticulate OM is often associated with oxygen stress. Several dominant polychaetes widely distributed in the PSR estuary have been considered as organic enrichment and low oxygen-tolerant initial colonizers (McCall 1977, Pearson and Rosenberg 1978, Diaz and Rosenberg 1995). The results suggest that macrobenthic communities in some areas of the continental shelf adjacent to the PSR are typical of slightly eutrophic conditions characteristic of quiescent estuarine environments. The high density of opportunistic species (mainly surface deposit feeders such as Spiophanes sp., Goniadides carolinae, Sphaerosyllis sp., Aricidea (Acmira) cf. taylori, Exogone sp., Prionospio cristata, Protodorvillea kefersteini and Mediomastus californiensis) supports the evidence for the eutrophication of some coastal areas along the southeastern Brazilian coast.

Coastal benthic communities are fuelled by a heterogeneous pool of organic detritus derived from various sources, such as phytoplankton blooms, vascular plant debris, winter blooms of seaweeds and in situ microalgal production. However, phytoplankton production along the southeast continental shelf of Brazil does not display strong seasonality compared with temperate waters (Ciotti et al. 2006), a finding that is reinforced by the stronger spatial correlation with most environmental and biological parameters than with temporal parameters. Higher amounts of chlorophyll $a$ were found at the shallower stations and of phaeopigments and $\mathrm{OC}$ at the deeper stations during this study. Therefore, most of this production will likely be recycled in the water column rather than deposited onto the coastal seabed, mainly at $<75 \mathrm{~m}$. In general, chloroplastic pigments are good indicators of the food energy that is readily available to the various benthic organisms (Giere 1993). OC may serve the same purpose, so food availability does not appears to be the limiting factor.

Previous studies have shown that there is an increase in the nutrient concentrations at the river mouth during the rainy season (Costa et al. 2009). However, higher amounts of chlorophyll $a$, phaeopigments and $\mathrm{OC}$ in both periods shows that even with less flow, the PSR contributes with nutrients that sustain primary production on the continental shelf. During the rainy season, this finding might be also related to the deeper penetration of the South Atlantic Central Water in the region of Cabo de São Tomé during the upwelling phenomenon in the spring and summer, a process that brings nutrient-rich waters to the study area (Silveira et al. 2000, 2004).

In summary, this paper presents a breakdown of the input of $\mathrm{OM}$ in the trophic chain via primary production in shallow waters $(<50 \mathrm{~m})$ and organic detritus in deeper waters $(75-100 \mathrm{~m})$, with species richness and abundance of benthic populations related to the PSR output. Two main macrofaunal assemblages were detected concurrently: (1) Spiophanes sp. and Phtisica marina, which are associated with $\mathrm{OC}$ and pheophytin at the deepest stations, and (2) Parexogone spp., $P$. macrochelis and Sphaerosyllis sp., which are associated with chlorophyll $a$ and temperature at most of the shallow stations. The contribution of different environmental variables between the macrofaunal associations and the evidence of differences in OM sources suggest that these associations occupy distinct niches along the continental shelf adjacent to the PSR, with species richness and abundance of benthic populations related to the river output.

\section{ACKNOWLEDGEMENTS}

This research was supported by PETROBRAS, within the project "Habitats: Environmental Heterogeneity of Campos Basin, Rio de Janeiro, Brazil".

\section{REFERENCES}

Akoumianaki I., Papaspyrou S., Kormas K.A., Nicolaidou A. 2013. Environmental variation and macrofauna response in a costal area influenced bu land runoff. Estuar. Coast. Shelf Sci. 132: $34-44$. http://dx.doi.org/10.1016/j.ecss.2012.04.009

Albuquerque A.L.S., Belem A.L., Zuluaga F.J.B., Cordeiro, L.G.M., Mendoza U., Knoppers B.A., Gurgel M.H.C., Meyers P.A., Capilla M. 2014. Particle Fluxes and Bulk Geochemical Characterization of the Cabo Frio Upwelling System in Southeastern Brazil: Sediment Trap Experiments between Spring 2010 and Summer 2012. An. Acad. Bras. Cienc. 86: 601-619. http://dx doi.org/10.1590/0001-37652014107212

Ambrogi R., Bedulli D., Zurlini G. 1990. Spatial and temporal patterns in structure of macrobenthic assemblages. A three-year study in the Northern Adriatic Sea in front of the Po river delta. Mar. Ecol. 11: 25-41.

http://dx.doi.org/10.1111/j.1439-0485.1990.tb00226.x

Anderson M.J. 2001. A new method for non-parametric multivariate analysis of variance. Austral Ecol. 26: 32-46.

Anderson M.J. 2005. PERMANOVA: A FORTRAN Computer Program for Permutational Multivariate Analysis of Variance. Department of Statistics, Univ. Auckland, Auckland, New Zealand

Carvalho C.E.V., Salomão M.S.M.B., Molisani M.M., Rezende C.E., Lacerda L.D. 2002. Contribution of a medium-sized tropical river to the particulate heavy-metal load for the South Atlantic Ocean. Sci. Total Environ. 284: 85-93 http://dx.doi.org/10.1016/S0048-9697(01)00869-5

Ciotti A.M., Rodriguez E.G., Andrade L., Paranhos R., Carvalho W.F. 2006. Clorofila $a$, medidas bio-ópticas e produtividade primária. In: Valentin, J.L. (ed.), Características Hidrobiológicas da Região da Zona Econômica Exclusiva brasileira. Vol. 1: 1st ed. Ideal Gráfica e Editora, Brasília, pp. 61-72.

Clarke K.R., Warwick R.M. 2001. Changes in Marine Communities: An Approach to Statistical Analysis and Interpretation. 2nd ed. PRIMER-E, Plymouth, UK.

Costa I.D., Di Beneditto A.P.M. 2009. Caracterización preliminary de los invertebrados bentónicos capturados accidentalmente em la pesca de camarones en el Norte del estado de Río de Janeiro, Sudeste de Brasil. Lat. Am. J. Aquat. Res. 37: 259-264. http://dx.doi.org/10.3856/vol37-issue2-fulltext-13

Costa L., Huszar V., Ovalle A. 2009. Phytoplankton functional groups in a tropical estuary: hydrological control and nutrient limitation. Estuaries Coasts. 32: 508-521 http://dx.doi.org/10.1007/s12237-009-9142-3

Crema R., Castelli A., Pravedelli D. 1991. Long term eutrophication effects on macrofaunal communities in northern Adriatic Sea. Mar. Pollut. Bull. 22: 503-508 http://dx doi.org/10.1016/0025-326X(91)90405-H

Dauer D.M., Alden R.W. 1995. Long-term trends in the macrobenthos and water quality of the lower Chesapeake Bay (19851991). Mar. Pollut. Bull. 30: 840-850. http://dx doi.org/10.1016/0025-326X(95)00091-Z

Dauwe B., Herman P.M.J., Heip H.R. 1998. Community and structure and bioturbation potential of macrofauna at four North sea stations with contrasting food supply. Mar. Ecol. Prog. Ser. 173: 67-83. http://dx.doi.org/10.3354/meps 173067

Diaz R.J., Rosenberg R. 1995. Marine benthic hypoxia - review of ecological effects and behavioral responses on macrofauna. 
Oceanogr. Mar. Biol. Annu. Rev. 33: 245-303.

Diaz-Castaneda V., Harris L. 2004. Biodiversity and structure of the polychaeta fauna from soft bottoms of Bahia Todos Santos, Baja California, Mexico. Deep Sea Res. Part II 51: 827-847. http://dx.doi.org/10.1016/j.dsr2.2004.05.007

Figueiredo R.O., Ovalle A.R.C., Rezende C.E., Martinelli L.A. 2011. Carbon and nitrogen in the lower basin of the Paraíba do Sul River, Southeastern Brazil: element fluxes and biogeochemical processes. Ambi-Agua. 6: 7-37. http://dx.doi.org/10.4136/ambi-agua. 183

Giere O. 1993. Meiobenthology. The Microscopic Motile Fauna in Aquatic Sediments. Springer-Verlag, Berlin, 527 pp.

Hedges J.I., Stern J. 1984. Carbon and nitrogen determinations of carbonate containing solids. Limnol. Oceanogr. 29: 657-663. http://dx.doi.org/10.4319/1o.1984.29.3.0657

Lana P.C., Camargo M.G., Brogim R.A., Isaac V.J. 1996. O Bentos da Costa Brasileira: Avaliação Crítica e Levantamento Bibliográfico (1856-1996). Femar, Rio de Janeiro, 432 pp.

Lardicci C., Abbiati M., Crema R., Morri C., Bianchi C.N., Castelli A. 1993. The distribution of polychaetes along enviromental gradients: an example from the Orbetello Lagoon, Italy. PSZNI Mar. Ecol. 14: 35-52. http://dx.doi.org/10.1111/j.1439-0485.1993.tb00363.x

Leninhan H.S., Micheli F. 2001. Soft-sediment communities. In: Bertness M.D., Gaines S.D., Hay M.E. (eds), Marine Community Ecology. Sinauer Associates, Sunderland, MA, pp. 253-287.

Liu K.K., Atkinson L., Quiñones R., Talaue-McManus L. 2010. Biogeochemistry of Continental Margins in a Global Context. In: Liu K.K., Atkinson L., Quiñones R., Talaue-McManus L. (eds), Carbon and Nutrient Fluxes in Continental Margins. A global synthesis. Berlin: Springer Verlag Heidelberg, pp. 3-24. http://dx.doi.org/10.1007/978-3-540-92735-8_1

Marengo J.A., Alves L.M. 2005. Tendências hidrológicas da bacia do Rio Paraíba do Sul. Rev. Bras. Meteorol. 20: 215-226.

Marsh A.G., Tenore K.R. 1990. The role of nutrition in regulating the population dynamics of opportunistic, surface deposit feeders in a mesohaline community. Limnol. Oceanogr. 35: 710-724. http://dx.doi.org/10.4319/1o.1990.35.3.0710

Mattos A.G.B. 2001. Análise da confiabilidade metrológica na determinação de pigmentos em ambientes marinhos por fluorimetria. M.Sc. dissertation, PUC, Rio de Janeiro, Brazil.

McCall P.L. 1977. Community patterns and adaptive strategies of the infaunal benthos of Long Island Sound. J. Mar. Res. 35: 321-366.

Moodley L., Heip C.H.R., Middelburg J.J. 1998. Benthic activity in sediments of the northwestern Adriatic Sea: sediment oxygen consumption, macro- and meiofauna dynamics. J. Sea Res. 40: 263-280. http://dx.doi.org/10.1016/S1385-1101(98)00026-4

Oliveira D.R.P., Cordeiro L.G.M.S., Carreira R.S. 2013. Characterization of organic matter in cross-margin sediment transects of an upwelling region in the Campos Basin (SW Atlantic, Brazil) using lipid biomarkers. Biogeochemistry 112: 311-327. http://dx.doi.org/10.1007/s10533-012-9726-z

Ovalle A.R.C., Silva C.F., Rezende C.E., Gatts C.E.N., Suzuki M.S., Figueiredo R.O. 2013. Long-term trends in hydrochemistry in the Paraíba do Sul River, southeastern Brazil. J. Hydrol. 481: 191-203. http://dx.doi.org/10.1016/j.jhydrol.2012.12.036

Parsons T.R., Maita Y., Lalli C.M. 1984. A Manual of Chemical and Biological Methods for Seawater Analysis. Pergamon Press, Oxford, UK, 173 pp.

Pearson T.H., Rosenberg R. 1978. Macrobenthic succession in relation to organic enrichment and pollution of the marine environment. Oceanogr. Mar. Biol. Annu. Rev. 16: 229-311.

Rabalais N.N., Turner R.E., Scavia D. 2002. Beyond science into policy: Gulf of Mexico hypoxia and the Mississippi River. BioScience. 52: 129-142.

http://dx.doi.org/10.1641/0006-3568(2002)052[0129:BSIPGO ]2.0. $\mathrm{CO} ; 2$
Rudorff N.M., Kampel M., Rezende C.E. 2011. Spectral mapping of the Paraíba do Sul plume (Brazil) using multitemporal Landsat images. J. Appl. Remote Sens. 5: 1-19. http://dx.doi.org/10.1117/1.3630220

Saavedra L., Dornelles L.M.A., Santos S.B., Absalão R., Anjos S.M.C., Melo G.V., Stanton N.S.G., Fonseca E.M., Lima L.M., Küsel E.T., Ribeiro E.O., Lazillotta A.A.A., Esteves F.A. 1999. Caracterização oceanográfica da plataforma continental interna adjacente ao Cabo Frio - RJ no inverno de 1995. In: Silva S.H.G., Lavrado H.P. (eds), Ecologia dos Ambientes Costeiros do Estado do Rio de Janeiro. Oecol. Brasil. 7: 245-271.

Santos L.N., Brotto D.S., Zalmon I.R. 2010. Fish responses to increasing distance from artificial reefs on the Southeastern Brazilian Coast. J. Exp. Mar. Biol. Ecol. 386: 54-60. http://dx.doi.org/10.1016/j.jembe.2010.01.018

Schmidt F., Hinrichs K.U., Elevert M. 2010. Sources, transport, and partitioning of organic matter at a highly dynamic continental margin. Mar. Chem. 118: 37-55. http://dx.doi.org/10.1016/j.marchem.2009.10.003

Seliger H.H., Boggs J.A., Biggley J.A. 1985. Catastrophic anoxia in the Chesapeake Bay in 1984. Science 228: 70-73. http://dx.doi.org/10.1126/science.228.4695.70

Silveira I.C.A., Schmidt A.C.K., Campos E.J.D.A. 2000. A corrente do Brasil ao largo da Costa Leste Brasileira. Rev. Bras. Oceanogr. 48: 171-183. http://dx.doi.org/10.1590/S1413-77392000000200008

Silveira I.C.A., Calado L., Castro B.M., Cirano M., Lima J.A.M., Mascarenhas A.S. 2004. On the baroclinic structure of the Brazil Current-Intermediate Western Boundary current system. Geophys. Res. Lett. 31: 1-5. http://dx.doi.org/10.1029/2004GL020036

Snelgrove P.V.R., Butman C.A. 1994. Animal-sediment relationships revisited: cause versus effect. Oceanogr. Mar. Biol. 32: 111-177.

Souza W.L.F., Knoppers B. 2003. Fluxos de água e sedimentos da costa leste do Brasil: relações entre a tipologia e as pressões antrópicas. Geochim. Brasil. 17(1): 57-74.

Souza T.A., Godoy J.M., Godoy M.L.D.P., Moreira I., Carvalho Z.L., Salomão M.S.M.B., Rezende C.E. 2010. Use of multitracers for the study of water mixing in the Paraíba do Sul River estuary. J. Environ. Radioact. 101: 564-570. http://dx.doi.org/10.1016/j.jenvrad.2009.11.001

Suguio K. 1973. Introdução à Sedimentologia. Edgard Blücher/ EDUSP, São Paulo, Brazil, 317 pp.

Ter Braak C.J.F. 1986. Canonical correspondence analysis: a new eigenvector techinique for multivariate direct gradient analysis. Ecology 67: 1167-1179. http://dx.doi.org/10.2307/1938672

Thrush S.F., Hewitt J.E., Cummings V., Ellis J.I., Hatton C., Lohrer A., Norkko A. 2004. Muddy waters: elevating sediment input to coastal and estuarine habitats. Front. Ecol. Environ. 2: 299-306. http://dx.doi.org/10.1890/1540-9295(2004)002[0299:MWESI T]2.0.CO;2

Weston D.P. 1990. Quantitative examination of macrobenthic community changes along an organic enrichment gradient. Mar. Ecol. Prog. Ser. 61: 233-244. http://dx.doi.org/10.3354/meps061233

Wijsman J.W.M., Herman P.M.J., Gomoiu M.T. 1999. Spatial distribution in sediment characteristics and benthic activity on the northwestern Black Sea shelf. Mar. Ecol. Prog. Ser. 181: 25-39. http://dx.doi.org/10.3354/meps 181025

Zalmon I.R., Novelli R., Gomes M.P., Faria V.V. 2002. Experimental results of an artificial reef program on the Brazilian coast north of Rio de Janeiro. ICES J. Mar. Sci. 59: 83-87. http://dx.doi.org/10.1006/jmsc.2002.1273

Zalmon I.R., Macedo I.M., Rezende C.E., Falcão A.P.C., Almeida T.C. 2013. The distribution of macrofauna on the inner continental shelf of southeastern Brazil: the major influence of an estuarine system. Estuar. Coast. Shelf Sci. 130: 169-178. http://dx.doi.org/10.1016/j.ecss.2013.03.001 
390 - I.L. Zalmon et al.

Appendix 1. - Environmental data (Sediment: $\mathrm{CaCO}_{3}$, total carbonate; MGS, mean grain size; sorting, OC, organic carbon; Chl $a$, chlorophyll $a$; Pheo, pheophytin. Water: T, temperature; S, salinity) for the 106 sampling sites during the dry (S) and rainy (C) periods of 2009. Stratum 1 ,

\begin{tabular}{|c|c|c|c|c|c|c|c|c|c|c|}
\hline Site & Season & Strata $(\mathrm{m})$ & $\mathrm{CaCO}_{3}(\%)$ & $\operatorname{MGS}(\theta)$ & Sorting $(\theta)$ & $\mathrm{OC}(\%)$ & $\mathrm{T}\left({ }^{\circ} \mathrm{C}\right)$ & $\mathrm{S}$ & Chl $a\left(\mu \mathrm{g} \mathrm{g}^{-1}\right)$ & Pheo $\left(\mu g^{-1}\right)$ \\
\hline D1 & Dry & $30 \mathrm{~m}$ & 2.73 & 0.42 & 1.31 & 0.28 & 16.3 & 36.2 & 1.17 & 4.15 \\
\hline D2 & Dry & $50 \mathrm{~m}$ & 0.57 & 0.68 & 0.91 & 0.18 & 15.7 & 35.6 & 1.21 & 1.74 \\
\hline D3 & Dry & $75 \mathrm{~m}$ & 7.44 & 1.48 & 2.57 & 0.59 & 15.5 & 35.6 & 1.97 & 2.16 \\
\hline E1 & Dry & $30 \mathrm{~m}$ & 2.89 & 3.25 & 1.62 & 0.54 & 17.3 & 36.2 & 2.04 & 4.31 \\
\hline E2 & Dry & $50 \mathrm{~m}$ & 1.67 & 1.03 & 0.80 & 0.12 & 15.3 & 35.5 & 1.68 & 1.33 \\
\hline E3 & Dry & $75 \mathrm{~m}$ & 1.55 & 1.94 & 1.28 & 0.20 & 14.5 & 35.4 & 1.27 & 3.37 \\
\hline E4 & Dry & $100 \mathrm{~m}$ & 4.19 & 3.22 & 1.31 & 0.36 & 14.8 & 35.4 & 0.74 & 3.97 \\
\hline $\mathrm{F} 1$ & Dry & $30 \mathrm{~m}$ & 0.11 & 0.57 & 0.46 & 0.28 & 22.9 & 36.5 & 1.89 & 0.48 \\
\hline $\mathrm{F} 2$ & Dry & $50 \mathrm{~m}$ & 0.67 & 1.42 & 0.59 & 0.28 & 18.5 & 36.0 & 2.17 & 4.27 \\
\hline F3 & Dry & $75 \mathrm{~m}$ & 2.31 & 2.71 & 0.88 & 0.19 & 14.5 & 35.4 & 1.42 & 10.5 \\
\hline $\mathrm{F} 4$ & Dry & $100 \mathrm{~m}$ & 2.01 & 1.81 & 1.41 & 0.25 & 14.4 & 35.4 & 0.33 & 3.16 \\
\hline G1 & Dry & $30 \mathrm{~m}$ & 0.36 & 1.14 & 1.28 & 0.21 & 23.3 & 36.5 & 1.95 & 1.00 \\
\hline G2 & Dry & $50 \mathrm{~m}$ & 0.58 & 1.39 & 0.54 & 0.08 & 15.4 & 35.6 & 1.99 & 1.97 \\
\hline G3 & Dry & $75 \mathrm{~m}$ & 6.68 & 0.98 & 2.80 & 0.48 & 23.0 & 36.8 & 2.47 & 3.04 \\
\hline G4 & Dry & $100 \mathrm{~m}$ & 8.88 & 3.17 & 3.19 & 0.53 & 23.3 & 36.9 & 1.25 & 2.81 \\
\hline $\mathrm{H} 1$ & Dry & $30 \mathrm{~m}$ & 0.13 & 0.87 & 0.87 & 0.08 & 24.0 & 36.7 & 3.46 & 0.62 \\
\hline $\mathrm{H} 2$ & Dry & $50 \mathrm{~m}$ & 9.41 & 1.29 & 1.38 & 0.32 & 21.1 & 36.5 & 2.39 & 1.39 \\
\hline $\mathrm{H} 3$ & Dry & $75 \mathrm{~m}$ & 9.23 & 3.34 & 3.98 & 0.54 & 19.5 & 36.3 & 2.74 & 3.99 \\
\hline $\mathrm{H} 4$ & Dry & $100 \mathrm{~m}$ & 9.49 & -1.14 & 2.98 & 0.49 & 17.6 & 35.9 & 0.42 & 2.20 \\
\hline I1 & Dry & $30 \mathrm{~m}$ & 0.50 & 0.79 & 0.69 & 0.10 & 22.5 & 36.7 & 1.46 & 0.55 \\
\hline $\mathrm{I} 2$ & Dry & $50 \mathrm{~m}$ & 8.77 & -1.43 & 3.98 & 0.73 & 20.8 & 36.5 & 1.68 & 3.79 \\
\hline I4 & Dry & $100 \mathrm{~m}$ & 8.67 & 4.40 & 2.91 & 0.45 & 17.6 & 35.9 & 0.94 & 4.42 \\
\hline 1 & Dry & $30 \mathrm{~m}$ & 2.69 & 0.36 & 0.93 & 0.17 & 24.6 & 36.4 & 2.10 & 0.87 \\
\hline 3 & Dry & $30 \mathrm{~m}$ & 3.13 & -0.31 & 0.57 & 0.18 & 23.9 & 36.6 & 1.65 & 0.55 \\
\hline 4 & Dry & $30 \mathrm{~m}$ & 3.38 & 1.43 & 3.40 & 1.53 & 25.4 & 35.5 & 1.05 & 4.05 \\
\hline 5 & Dry & $30 \mathrm{~m}$ & 4.45 & 2.02 & 3.86 & 0.29 & 26.1 & 34.3 & 0.89 & 1.18 \\
\hline 6 & Dry & $30 \mathrm{~m}$ & 1.21 & 1.53 & 0.58 & 0.15 & 24.6 & 36.2 & 0.57 & 0.61 \\
\hline 7 & Dry & $30 \mathrm{~m}$ & 0.49 & 4.67 & 1.89 & 0.10 & 24.8 & 36.3 & 1.23 & 0.33 \\
\hline 8 & Dry & $30 \mathrm{~m}$ & 4.13 & 5.25 & 2.15 & 1.13 & 16.7 & 35.7 & 1.47 & 6.15 \\
\hline 9 & Dry & $50 \mathrm{~m}$ & 0.68 & 0.59 & 0.55 & 0.14 & 16.8 & 35.8 & 0.40 & 1.16 \\
\hline 10 & Dry & $30 \mathrm{~m}$ & 0.22 & 0.76 & 0.67 & 0.13 & 25.0 & 36.6 & 3.71 & 1.04 \\
\hline 11 & Dry & $30 \mathrm{~m}$ & 0.19 & 0.66 & 0.78 & 0.08 & 24.5 & 36.6 & 2.04 & 0.58 \\
\hline 12 & Dry & $30 \mathrm{~m}$ & 1.34 & 1.43 & 1.93 & 0.14 & 24.4 & 36.5 & 2.58 & 1.02 \\
\hline 13 & Dry & $30 \mathrm{~m}$ & 0.64 & 1.22 & 0.84 & 0.09 & 23.7 & 36.6 & 3.22 & 0.78 \\
\hline 14 & Dry & $30 \mathrm{~m}$ & 9.24 & 1.24 & 3.50 & 0.31 & 23.7 & 36.5 & 1.60 & 1.41 \\
\hline 16 & Dry & $30 \mathrm{~m}$ & 11.6 & -0.53 & 1.91 & 0.32 & 23.5 & 36.5 & 4.83 & 1.52 \\
\hline 17 & Dry & $30 \mathrm{~m}$ & 1.00 & 1.73 & 0.75 & 0.16 & 23.3 & 36.7 & 3.56 & 1.28 \\
\hline 18 & Dry & $30 \mathrm{~m}$ & 0.22 & 0.73 & 0.68 & 0.15 & 23.9 & 36.6 & 1.91 & 0.53 \\
\hline 20 & Dry & $30 \mathrm{~m}$ & 0.22 & 2.26 & 0.62 & 0.15 & 24.8 & 36.6 & 6.31 & 1.15 \\
\hline 21 & Dry & $50 \mathrm{~m}$ & 0.68 & 0.30 & 0.84 & 0.15 & 16.7 & 35.8 & 0.31 & 0.50 \\
\hline 23 & Dry & $50 \mathrm{~m}$ & 2.49 & 1.69 & 2.44 & 0.23 & 19.0 & 36.2 & 2.90 & 5.05 \\
\hline 24 & Dry & $30 \mathrm{~m}$ & 0.18 & 0.61 & 0.86 & 0.15 & 23.7 & 36.7 & 3.48 & 0.75 \\
\hline 25 & Dry & $30 \mathrm{~m}$ & 0.40 & 0.55 & 0.70 & 0.11 & 23.1 & 36.7 & 2.95 & 0.70 \\
\hline 27 & Dry & $30 \mathrm{~m}$ & 1.81 & 0.87 & 0.79 & 0.18 & 22.2 & 36.6 & 3.71 & 0.99 \\
\hline 29 & Dry & $30 \mathrm{~m}$ & 6.28 & 0.78 & 0.85 & 0.27 & 21.2 & 36.5 & 3.19 & 0.91 \\
\hline 30 & Dry & $30 \mathrm{~m}$ & 0.59 & 0.70 & 0.71 & 0.16 & 24.8 & 36.7 & 2.51 & 0.75 \\
\hline 31 & Dry & $30 \mathrm{~m}$ & 0.15 & 1.07 & 0.75 & 0.10 & 23.3 & 36.7 & 2.77 & 0.65 \\
\hline 32 & Dry & $50 \mathrm{~m}$ & 1.46 & 3.70 & 1.47 & 0.17 & 19.8 & 36.3 & 0.84 & 1.59 \\
\hline 33 & Dry & $75 \mathrm{~m}$ & 1.06 & 1.02 & 0.77 & 0.13 & 14.9 & 35.5 & 1.67 & 1.40 \\
\hline 34 & Dry & $50 \mathrm{~m}$ & 1.13 & 3.67 & 1.14 & 0.21 & 22.2 & 36.7 & 0.88 & 5.87 \\
\hline 41 & Dry & $75 \mathrm{~m}$ & 8.14 & 1.56 & 2.95 & 0.33 & 23.1 & 36.9 & 0.52 & 0.71 \\
\hline 43 & Dry & $100 \mathrm{~m}$ & 2.15 & 2.57 & 1.89 & 0.28 & 14.5 & 35.4 & 0.61 & 4.54 \\
\hline D1 & Rainy & $30 \mathrm{~m}$ & 0.40 & -0.36 & 0.64 & 0.16 & 21.6 & 36.0 & 0.08 & 0.28 \\
\hline D2 & Rainy & $50 \mathrm{~m}$ & 0.82 & 1.03 & 0.83 & 0.55 & 19.2 & 35.9 & 0.53 & 0.99 \\
\hline D3 & Rainy & $75 \mathrm{~m}$ & 7.04 & 0.64 & 2.56 & 0.91 & 17.8 & 35.9 & 3.41 & 5.29 \\
\hline E1 & Rainy & $30 \mathrm{~m}$ & 3.43 & 4.44 & 1.99 & 0.63 & 21.5 & 35.7 & 1.69 & 3.10 \\
\hline E2 & Rainy & $50 \mathrm{~m}$ & 1.67 & 0.89 & 0.65 & 0.76 & 19.1 & 35.9 & 0.54 & 0.47 \\
\hline E3 & Rainy & $50 \mathrm{~m}$ & 1.76 & 2.11 & 1.49 & 0.25 & 18.9 & 36.1 & 0.80 & 2.05 \\
\hline E4 & Rainy & $100 \mathrm{~m}$ & 4.20 & 2.38 & 1.90 & 0.38 & 16.9 & 35.8 & 1.13 & 3.98 \\
\hline $\mathrm{F} 1$ & Rainy & $30 \mathrm{~m}$ & 0.09 & 0.47 & 0.51 & 0.10 & 21.0 & 35.9 & 1.21 & 0.18 \\
\hline $\mathrm{F} 2$ & Rainy & $50 \mathrm{~m}$ & 9.78 & 1.08 & 0.72 & 0.09 & 19.9 & 36.1 & 0.74 & 0.70 \\
\hline $\mathrm{F} 3$ & Rainy & $75 \mathrm{~m}$ & 2.51 & 2.59 & 0.90 & 0.27 & 19.5 & 36.1 & 0.77 & 2.71 \\
\hline $\mathrm{F} 4$ & Rainy & $100 \mathrm{~m}$ & 2.45 & 1.04 & 0.90 & 0.15 & 17.4 & 35.8 & 0.54 & 2.49 \\
\hline G1 & Rainy & $30 \mathrm{~m}$ & 0.28 & 1.91 & 0.78 & 0.21 & 22.8 & 36.2 & 2.16 & 0.70 \\
\hline G2 & Rainy & $50 \mathrm{~m}$ & 0.64 & 1.28 & 0.57 & 0.60 & 20.3 & 36.1 & 0.49 & 0.58 \\
\hline G3 & Rainy & $75 \mathrm{~m}$ & 7.32 & 0.94 & 3.23 & 0.57 & 19.6 & 36.2 & 2.92 & 3.91 \\
\hline G4 & Rainy & $100 \mathrm{~m}$ & 7.98 & 1.41 & 3.93 & 0.64 & 19.9 & 36.2 & 0.90 & 2.99 \\
\hline H1 & Rainy & $30 \mathrm{~m}$ & 0.08 & 1.12 & 0.82 & 0.12 & 22.6 & 36.5 & 4.10 & 0.63 \\
\hline $\mathrm{H} 2$ & Rainy & $50 \mathrm{~m}$ & $<0.05$ & 0.98 & 0.86 & 0.45 & 20.9 & 36.4 & 1.33 & 0.83 \\
\hline H3 & Rainy & $75 \mathrm{~m}$ & 8.48 & 2.72 & 4.33 & 0.92 & 18.0 & 36.0 & 2.60 & 4.50 \\
\hline $\mathrm{H} 4$ & Rainy & $100 \mathrm{~m}$ & 9.03 & 0.40 & 2.31 & 0.75 & 17.4 & 35.9 & 1.91 & 4.56 \\
\hline I1 & Rainy & $30 \mathrm{~m}$ & 0.12 & 0.45 & 1.01 & 0.11 & 22.0 & 36.3 & 2.43 & 0.37 \\
\hline $\mathrm{I} 2$ & Rainy & $50 \mathrm{~m}$ & 9.34 & 3.65 & 4.12 & 0.73 & 21.7 & 36.1 & 1.87 & 4.33 \\
\hline I4 & Rainy & $100 \mathrm{~m}$ & 8.64 & 3.17 & 3.33 & 0.56 & 21.5 & 36.4 & 0.68 & 3.88 \\
\hline 1 & Rainy & $30 \mathrm{~m}$ & 0.55 & 0.33 & 0.99 & 0.11 & 22.4 & 35.5 & 1.88 & 0.32 \\
\hline
\end{tabular}


Estuarine dynamics and macrobenthos spatial variability $\mathbf{3 9 1}$

\begin{tabular}{|c|c|c|c|c|c|c|c|c|c|c|}
\hline Site & Season & Strata $(m)$ & $\mathrm{CaCO}_{3}(\%)$ & $\operatorname{MGS}(\theta)$ & Sorting $(\theta)$ & $\mathrm{OC}(\%)$ & $\mathrm{T}\left({ }^{\circ} \mathrm{C}\right)$ & $S$ & Chl $a\left(\mu \mathrm{g} \mathrm{g}^{-1}\right)$ & Pheo $\left(\mu \mathrm{g} \mathrm{g}^{-1}\right)$ \\
\hline 3 & Rainy & $30 \mathrm{~m}$ & 7.62 & 0.51 & 1.35 & 0.16 & 22.4 & 35.3 & 2.5 & 0.58 \\
\hline 4 & Rainy & $30 \mathrm{~m}$ & 3.23 & 6.96 & 1.54 & 1.13 & 22.4 & 35.4 & 4.36 & 11.8 \\
\hline 5 & Rainy & $30 \mathrm{~m}$ & 4.84 & 1.25 & 3.92 & 0.34 & 22.4 & 35.3 & 1.13 & 1.55 \\
\hline 6 & Rainy & $30 \mathrm{~m}$ & 0.89 & 0.90 & 0.79 & 0.06 & 22.3 & 35.2 & 0.71 & 0.25 \\
\hline 7 & Rainy & $30 \mathrm{~m}$ & 0.21 & 0.44 & 1.05 & 0.05 & 21.2 & 35.8 & 1.49 & 0.24 \\
\hline 8 & Rainy & $30 \mathrm{~m}$ & 0.29 & 1.22 & 1.61 & 0.32 & 21.7 & 35.9 & 0.03 & 0.10 \\
\hline 9 & Rainy & $50 \mathrm{~m}$ & 0.59 & 1.15 & 0.70 & 0.09 & 20.8 & 36.0 & 0.30 & 0.34 \\
\hline 10 & Rainy & $30 \mathrm{~m}$ & 0.14 & 1.17 & 0.65 & 0.32 & 21.3 & 35.8 & 2.24 & 0.39 \\
\hline 11 & Rainy & $30 \mathrm{~m}$ & 0.26 & 1.76 & 0.86 & 0.31 & 22.3 & 36.0 & 2.19 & 0.37 \\
\hline 12 & Rainy & $30 \mathrm{~m}$ & 1.04 & 1.97 & 0.86 & 0.06 & 22.6 & 36.3 & 4.34 & 0.95 \\
\hline 13 & Rainy & $30 \mathrm{~m}$ & 0.19 & 1.38 & 0.74 & 0.10 & 22.4 & 35.9 & 5.01 & 0.54 \\
\hline 14 & Rainy & $30 \mathrm{~m}$ & 1.08 & 1.14 & 0.75 & 0.18 & 22.4 & 35.7 & 3.16 & 0.70 \\
\hline 16 & Rainy & $30 \mathrm{~m}$ & 11.5 & -0.31 & 1.16 & 0.46 & 22.4 & 35.7 & 6.79 & 1.46 \\
\hline 17 & Rainy & $30 \mathrm{~m}$ & 0.71 & 1.33 & 0.84 & 0.17 & 22.3 & 36.1 & 3.76 & 0.87 \\
\hline 18 & Rainy & $30 \mathrm{~m}$ & 0.11 & 1.06 & 0.78 & 0.06 & 22.1 & 35.8 & 6.81 & 0.01 \\
\hline 19 & Rainy & $30 \mathrm{~m}$ & 0.20 & 0.95 & 0.79 & 0.05 & 22.6 & 36.4 & 4.86 & 0.66 \\
\hline 20 & Rainy & $30 \mathrm{~m}$ & 0.11 & 2.08 & 0.63 & 0.09 & 21.3 & 35.8 & 5.06 & 0.69 \\
\hline 21 & Rainy & $50 \mathrm{~m}$ & 0.41 & 0.85 & 0.72 & 0.21 & 20.2 & 35.9 & 0.30 & 0.29 \\
\hline 23 & Rainy & $50 \mathrm{~m}$ & 3.06 & 1.18 & 2.65 & 0.37 & 21.1 & 35.9 & 2.50 & 8.13 \\
\hline 24 & Rainy & $30 \mathrm{~m}$ & 0.13 & 1.31 & 0.57 & 0.06 & 22.0 & 36.1 & 3.25 & 0.62 \\
\hline 25 & Rainy & $30 \mathrm{~m}$ & 0.28 & 0.76 & 0.77 & 0.09 & 22.1 & 36.4 & 3.68 & 0.68 \\
\hline 27 & Rainy & $30 \mathrm{~m}$ & 1.43 & 1.07 & 0.77 & 0.22 & 22.0 & 36.3 & 2.56 & 0.52 \\
\hline 29 & Rainy & $30 \mathrm{~m}$ & 4.95 & 0.76 & 0.75 & 0.15 & 22.2 & 36.4 & 3.03 & 0.85 \\
\hline 30 & Rainy & $30 \mathrm{~m}$ & 0.52 & 0.83 & 0.72 & 0.11 & 21.9 & 36.4 & 3.42 & 0.40 \\
\hline 31 & Rainy & $30 \mathrm{~m}$ & 0.53 & 1.19 & 0.79 & 0.10 & 23.1 & 36.6 & 3.70 & 0.50 \\
\hline 32 & Rainy & $50 \mathrm{~m}$ & 1.09 & 1.27 & 0.66 & 0.13 & 21.7 & 36.1 & 0.79 & 1.55 \\
\hline 33 & Rainy & $75 \mathrm{~m}$ & 8.06 & 0.84 & 2.08 & 0.34 & 14.0 & 35.3 & 1.12 & 2.15 \\
\hline 34 & Rainy & $50 \mathrm{~m}$ & 2.01 & 1.81 & 0.84 & 0.27 & 20.0 & 36.2 & 1.36 & 5.92 \\
\hline 41 & Rainy & $75 \mathrm{~m}$ & 0.33 & 0.73 & 1.84 & 0.38 & 21.1 & 36.5 & 0.96 & 2.09 \\
\hline 43 & Rainy & $100 \mathrm{~m}$ & 1.72 & 2.33 & 1.21 & 0.24 & 18.6 & 36.1 & 0.51 & 1.77 \\
\hline
\end{tabular}

